\title{
SOME ASPECTS OF MACROECONOMIC STABILITY AND TRANSFORMATION (EXAMPLE OF POLAND AND GEORGIA)
}

\author{
GRAŻYNA KARMOWSKA \\ Associate Professor \\ West Pomeranian University of Technology in Szczecin, Poland \\ grazyna.karmowska@zut.edu.pl
}

\section{NINO MIKIASHVILI}

\author{
Associate Professor \\ Ivane Javakhishvili Tbilisi State University, Georgia, \\ nino.mikiashvili@tsu.ge
}

\begin{abstract}
The most distinctive shifts in the economic system began at the end of the last century, in the form of economic formation transformation, one of the most important political and economic processes. This process affected certain group of countries, which had to transform into the market economy. Thus, there was an inevitable necessity to adjust the macroeconomic policy and regulation. This paper aims is to describe and analyze the difficulties, problems and challenges that occurred during the last years. We will try to focus on issues of macroeconomic stability and the role of a government in the sustainable development of the country for example Poland and Georgia. The paper highlights the importance of stability of the economy for Poland and Georgia. The paper describes the current economic situation and its short-term perspectives by using the Economic Discomfort Index and uses the Rule of Law Index to identify the degree of realization of the state functions to develop the legislative base, improve the competitive environment, etc. The aspects of macroeconomic stability and transformation are considered on the example of the economics of Poland and Georgia, with the former one being and the latter making efforts to become the EU member.
\end{abstract}

KEYWORDS: TRANSITIONAL ECONOMIES, MACROECONOMIC STABILIZATION, MACROECONOMIC POLICY, ECONOMIC DEVELOPMENT, COMPARATIVE STUDIES OF COUNTRIES, EDI.

For citation: Karmowska G., Mikiashvili N. (2021). Some Aspects of Macroeconomic Stability and Transpormation (Example of Poland and Georgia). Globalization and Business, №11, pp35-42. https://doi.org/10.35945/gb.2021.11.004

\section{INTRODUCTION}

The last decades featured significant changes in the world economy. Besides the economic aspects, political, social, ecological and other factors are getting more active, which modifies the traditional perspectives. The most distinctive shifts in the economic system began at the end of the last century, in the form of post-communist transformation, one of the most important political and economic processes. The process affected certain group of countries, which had to transform their economies. There was an inevitable necessity to adjust the existing institutions.

There was no exact prescription for the economic transformation, from command economy towards market-based one, at the initial period of transition, nor exists such formula even in modern economics (Papava, V. 2003). Therefore, mistakes were made by the countries themselves and by inter- national organizations as well. International monetary institutions were helping post-socialist countries in various forms, such as financial resources, technical assistance and recommendations (Berend, T. I. (2009). The support of the international institutions was very important since without their assist the post-socialist countries themselves had neither the resources nor the experience to implement drastic reforms and transform into the market economy (Papava, V. 2013). Thus, the international organizations have an important role in the process of transformation, in the establishment of the market-based institutions and in organizing the basis for the economic development of these countries.

The countries with better initial conditions and a more aggressive approach to reforms achieved stabilization more quickly. A clear example is Poland, which, despite being closely integrated with the socialist economic countries, owing to its state attributes (national currency is a sufficient example 
of this) could complete the process of transformation more quickly and became a full member of the EU economic system (Sachs, J. (1993).

The lack of state attributes of an independent state, military opposition and rude violations of the law supremacy principle rather prolonged the process of economic and political transformation of Georgia (Wheatley, J. (2017). consequently, the time to use to realize swift and efficient reforms was 'lost'. Due to miserable historical twists and turns, Georgia is still preparing to become a part of the EU, while Poland, side by side with other post-socialist countries, has been an EU member since 2004.

Also, it must be emphasized, that there are no specific and generally accepted criteria, by which it is possible to determine whether the transformation process is already completed or not. Becoming a member of the European Union is considered to be one of the criteria. If the EU decides that the economy of the country, which is in the process of transition, is ready to be a Union member, it most likely means that the transition has completed and the economy of the country operates according to the market principles. Poland has gone through this process, and Georgia must go through it.

The process of reforming was also influenced by non-economical factors, such as the level of sociopolitical development in the society, the experience accumulated by the State, national mentality, leadership, etc.

Poland and Georgia were overburdened with the whole complexity of the transformation process and suffered from the shocks of the economic and political systems. The most pressing challenge was creating a competitive economy. Creating, maintaining and developing a competitive economy has been, is and will be the most important issue for countries (Kolodko, G.W. 2019). The absence of large internal resources and savings is due to foreign dependent investments. It must be emphasized, that getting interested from investors of a large scale, requires relevant legislation, modern infrastructure, a steady macroeconomic environment and assurance of political safety. In this regard, especially Poland and also Georgia has made significant progress (Mikiashvili, N. \& Karmowska G. 2019).

The process of European integration became more active during the 1990s, and as a result of strengthening and deepen partnership, several of the post-communist countries were accepted in EU as the members (Poland, Czech Republic, Lithuania, Latvia, Slovakia, Hungary, Estonia and Slovenia), followed by Bulgaria and Romania (2007) and Croatia (2013). These countries have advanced and completed the transformation process, while in other countries, including Georgia, this process was relatively delayed. Georgia was overburdened with the whole complexity of the transformation process and suffered from the shocks of the economic and political systems (Papava, V. 2016).

However, it should be noted, that despite relatively high rates of economic growth, the model of economic development in Georgia is rather a consumer model, than an innovative and productive model.

There have been attempts to normalize the economics and make it less dependent on import, stimulate novelties, etc., but the years pass and no essential positive outcomes are seen in this regard. The development of the real sector of the economy is one of the most crucial factors for ensuring macroeconomic stability. As for the economy of Poland, it is advanced in this respect as evidenced by relevant macroeconomic and international indices (Karmowska, G \& Mikiashvili, N. 2020). A country striving for sustainable development and increased competitiveness must formulate a social and economic development plan based on the following principles: ensuring rapid and efficient economic growth, which is oriented towards the development of the real sector of the economy; pursuing economic policy, that stimulates inclusive economic growth; and ensuring ecological safety and sustainability, and rational usage of natural resources.

\section{METHODOLOGY AND DATA COLLECTION}

The methodological basis of the writing of the article became the general scientific methods of cognition (dialectics, analysis, synthesis, systemic, analogy, historicism, system analysis). The data used for analysis was taken from the websites of the official, non-governmental and international organizations. The mathematical and econometric apparatus was used to identify and describe interrelations between various indicators.

The main focus of the research process was on two indices. These are the Economic Discomfort Index and Rule of Law Index. The Economic Discomfort index helps determine how the average citizen is doing economically, while the Rule of Law Index allows describing the legal and political environment that predominantly determines a country's stability and attractiveness. One of the components of EDI is the focus on unemployment levels. Diagrams are constructed and regression models for economic analysis and forecasting are recorded. Various scientific articles, legislative acts, reports of the international organizations and other works have been studied in the process of writing this paper.

\section{"SHOCK THERAPY" IN POLAND AND GEORGIA}

In 1991, after collapsing the communist regime, Poland was one of the first countries, where the process of transition into the market economy has started with the method of "Shock Therapy". The "Shock Therapy", also termed Balcerowicz Plan, was a method for rapidly transitioning from an economy based on state ownership and central planning, to a capitalist market economy. Poland was followed by Russia, in the January of 1992 Russia began to realize "Shock Therapy", and one month later realization of the Russian version of the Balcerowicz Plan began in Georgia as well. It should be mentioned, that the impact of Polish experience and Polish economists on the executed (and not accomplished) economic reforms in independent Georgia is significantly large.

The Balcerowicz Plan could not be executed in Georgia, because for several objective and subjective reasons. The execution of the "Shock Therapy" requires consistent use of the 
Monetary and Fiscal institutions. In the case of the absence of these institutes, the method of "Shock Therapy" can't be used fully, and every attempt is doomed to failure. This thesis can be proved with Georgian experience.

Famous Georgian economist, Vladimer Papava has studied the transformation period thoroughly. In his book "Macroeconomics of Post-Communist Transformation" (Papava, V. 2005) he has analyzed each paragraph of the Balcerowicz Plan and the possibilities and difficulties of implementation of this plan in Georgia. We will try to formulate the main problems that Georgia has encountered at the beginning of the transformation process. First, we will discuss the example of Poland.

During the initial stage of "Shock Therapy", the following measures have been executed simultaneously in Poland:

1. Deliberate encourage of the inflation processes to achieve equilibrium on the market;

2. "Strict" restriction of the population incomes;

3. Significant increase of the interest rates, reduction of the quantity of money in circulation (saving incentives);

4. Reduction of budget expenditures, at the expense of reducing capital investments and subsidies for the unprofitable enterprises;

5. Emission of the government bonds to cover the deficit of the state budget;

6. Regulation and unification of the tax system;

7. Introduction of the unified exchange rate of Zloty to US Dollar, provision of conversion of Zloty on the internal market;

8. Introduction of new customs duty to restrict the import and stimulate the export;

9. Provision of the public assistance within the actual capability of the government;

10. Elimination of the monopolistic structures and rejection of administrative interference in business activities by the state.

It should also be noted that according to most economists, Balcerowicz "shock therapy" was justified in Poland and the country was able to transform rapidly.

After reviewing the original Balcerowicz Plan we can analyze to what extent it was adopted in Georgia. We will discuss each direction of the "Shock Therapy" separately:

1. To achieve the market equilibrium, the regulated prices on goods and services in Georgia have significantly increased, only in 1991 CPI was 180\%, and for 1992 this index increased up to 25 times. It can be said, that the first paragraph of the Balcerowicz Plan was carried out in Georgia.

2. Despite the fact, that there was not taken any harsh regulatory measure in Georgia (as it was carried out in Poland) that would restrict the growth of the wage fund, the increase of salaries and social assistance had been evidently behind the price growth. Therefore, it can be considered that the second paragraph of the Balcerowicz Plan more or less was executed in Georgia.

3. In 1991-92 Georgia had not had its monetary system (there were circulating Rubles of the dissolved Soviet Union and newly introduces Russian Rubles), thus Georgia couldn't restrict the quantity of money in circulation by increasing interest rate. Georgia had managed to accumulate some amount of money on deposits with the condition of doubling the funds, but in the second half of 1992 due to complications of bringing cash from Russia (Russia had remained the money issuer), the money accumulated on deposits had been used to pay salaries and pensions. Thus, the execution of the third paragraph was a failure.

4. In 1992 the share of the state capital investments in the state budget had not declined, while the volume of the donations had increased up to 5 times. The fourth paragraph was not fulfilled as well.

5. Government bonds practically had not been used as the instrument to cover the deficit of the state budget;

6. The regulation of the tax system in Georgia had already begun in the summer of 1991, therefore the sixth paragraph of the "Shock Therapy" can be considered as accomplished.

7. In 1992 Georgia had not had national currency, so it was practically impossible to execute the seventh paragraph.

8. In 1992 unified customs duty had been introduced, the rate of import duty was $2 \%$, and the rate of export duty was $8 \%$. These rates could neither restrict the import nor stimulate the export. So, neither the eighth paragraph was executed.

9. In 1991-92 there had not existed any special assistance programs for low-income families in Georgia, and the social security system did not recognize assistance differentiation according to income levels of the families. Therefore, unfortunately, the ninth paragraph could not be carried out.

10. In 1992 for the first time, Georgia had adopted legislative and governmental decisions about the restriction of monopolistic activities and encouraging the development of the competitive market. As expected, the execution of these decisions within a short period could not be realized comprehensively and on large scale.

Consequently, only 3 paragraphs out of 10 paragraphs of the Balcerowicz Plan, the classical scheme of the "Shock Therapy" for post-communist countries, have been accomplished in Georgia. Could not be executed such important measures as the abolishment of budget subsidies and strict reduction of the quantity of money in circulation.

In the first half of the 1990s, the output decreased significantly, trade linkages and internal economic relations collapsed. Inflation has increased to such an extent, that the regulation of the exchange rate became meaningless. Because of the hyperinflation, the National Bank was trying to adopt a strict monetary policy. The National Bank intended to regulate inflation and provide economic growth and currency stability. This goal was prevented by the fiscal crisis in Georgia and external factors, such as the economic crisis in Russia and other partner countries of the regional organization - The Commonwealth of Independent States (CIS).

In 1998 the economic crisis in CIS countries deepened. In the conditions of strong external shock and deepened internal fiscal crisis the behaviour of the economic agents changed drastically. Changes in behaviour reflected in excessive demand for foreign currency. In 2000 the global financial and economic situation has improved. The reforms, 
implemented during the first decade of the transformation process had paid off and after the beginning of the 2000s, the countries achieved macroeconomic stability. And more intensive integration into the global economy increased capital flows to these countries. The foreign direct investments (FDI) had positive subsequent effects, such as new jobs, access to advanced technologies, the appearance of new products and new market segments. Tax privileges and simplified bureaucratic procedures are not enough measures to interest investors of large scale. As the international practice shows, in the case of temporary tax privileges majority of investors leave the country after the expiration of these privileges. Besides, the implemented reforms often were inconsistent and spontaneous. Despite high economic growth in several years, benefits did not reach the majority of the population.

The government can formulate a strategy for socio-economic development, which is based on three main principles: ensuring rapid and efficient economic growth, which is oriented towards the development of the real sector of the economy; pursuing economic policy, that stimulates inclusive economic growth; and ensuring ecological safety and sustainability, and rational usage of natural resources.

The priority of the government is to solve the problems which obstruct the economic policy from achieving its primary goal - inclusive economic growth. After analyzing the Georgian economic conjuncture, some problems were revealed, which hinder economic growth, such as low competitiveness of the private sector, incompetent human resources and limited access to financial resources. In the case of Poland, most of the similar problems have been overcome.

\section{MACROECONOMIC POLICY'S ASPECTS AND SOME GLOBAL WORLD INDEX}

Macroeconomic policy has several important goals: economic growth, full employment, economic efficiency, price stability, social peace, balanced and positive balance of pay- ments and others. As we know economic growth is directly related to the growth of capital, herewith an important issue is the effective use of this capital. Capital growth can be at the expense of investments in both physical and human capital.

One of the most pressing problems Georgia faces is the consumer model of the economy. Unfortunately, economic development policy usually is directed to the stimulation of consumption, not to the growth of productivity. Without a developed real sector it is impossible to achieve an economically strong country with a stable macroeconomic. In the consumption-oriented economy of Georgia import exceeds export more than three times. This imbalance is financed partly by foreign direct investments, partly by revenues from tourism and also from the transfers of Georgian citizens who live abroad. The real sector in Poland is well developed. Therefore, when comparing the volume of production per capita, the contrast is obvious (Chart 1).

For the development of the economy in general, advancement in the process of European integration has a significant meaning. In this regard, Georgia has succeeded. On June 27, 2014, Georgia signed an Association Agreement with the European Union, and one of the most important parts of the agreement is DCFTA - Deep and Comprehensive Free Trade Area. Negotiation processes for DCFTA had begun in 2009. After signing this agreement Georgia has undertaken obligations in various fields, such as intellectual property rights, quality care, sanitary and phytosanitary measures, food safety strategy and the program of approximation of the legislation. The government tries to overcome this obstacle with various measures, such as informing manufacturers about the specific requirements, introducing new regulations and establishing new institutional bodies (Mikiashvili, N. \& Chokheli, E. 2013).

The modern world is inconceivable without deepening interrelations, which is the concomitant process of globalization. That is why the regional aspects of the problem should be highlighted. As for Georgia, EU integration is a fundamental matter for both, domestic and foreign policy.

Chart 1. GDP per capita (constant 2010 US\$) in Poland\&Georgia during 1990-2019 years

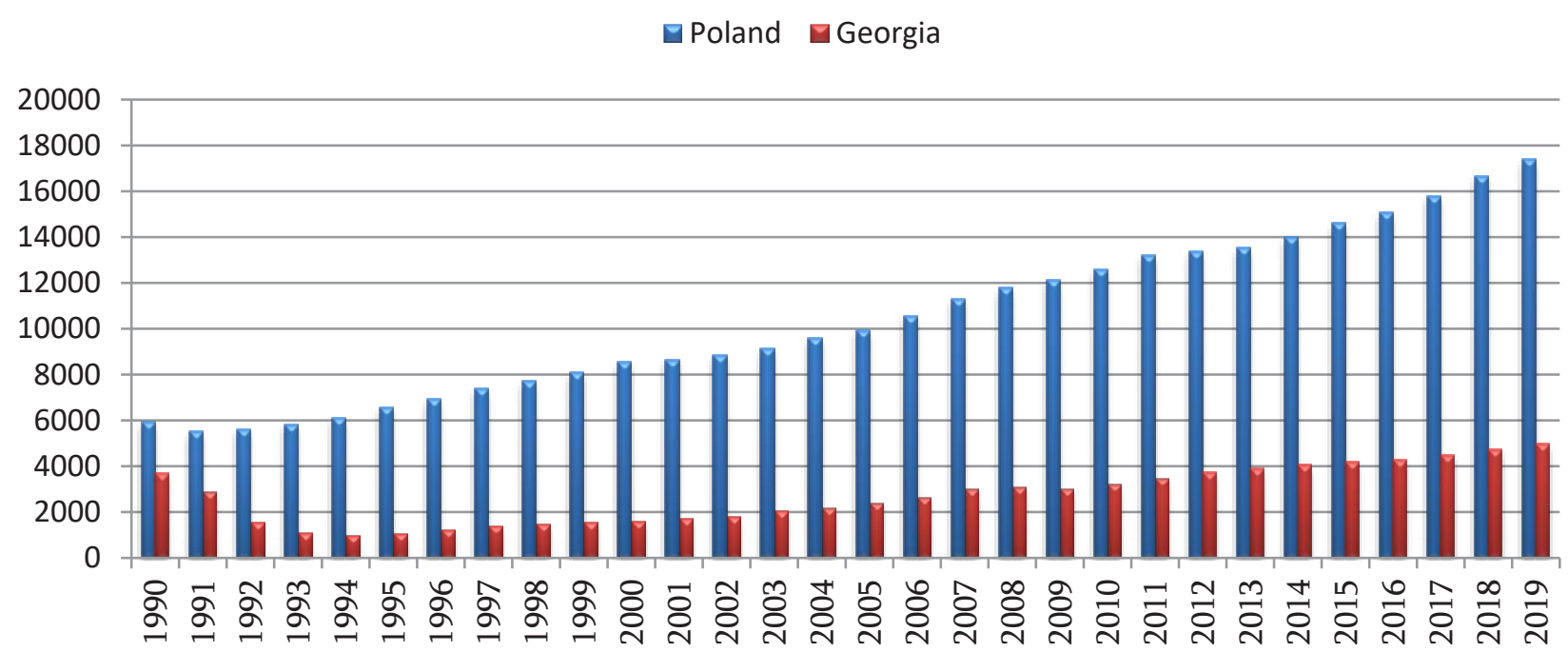

Source: The World Bank Open Data 
Chart 2. CPI \& Unemployment Rate of Poland and Georgia (2000-2020).

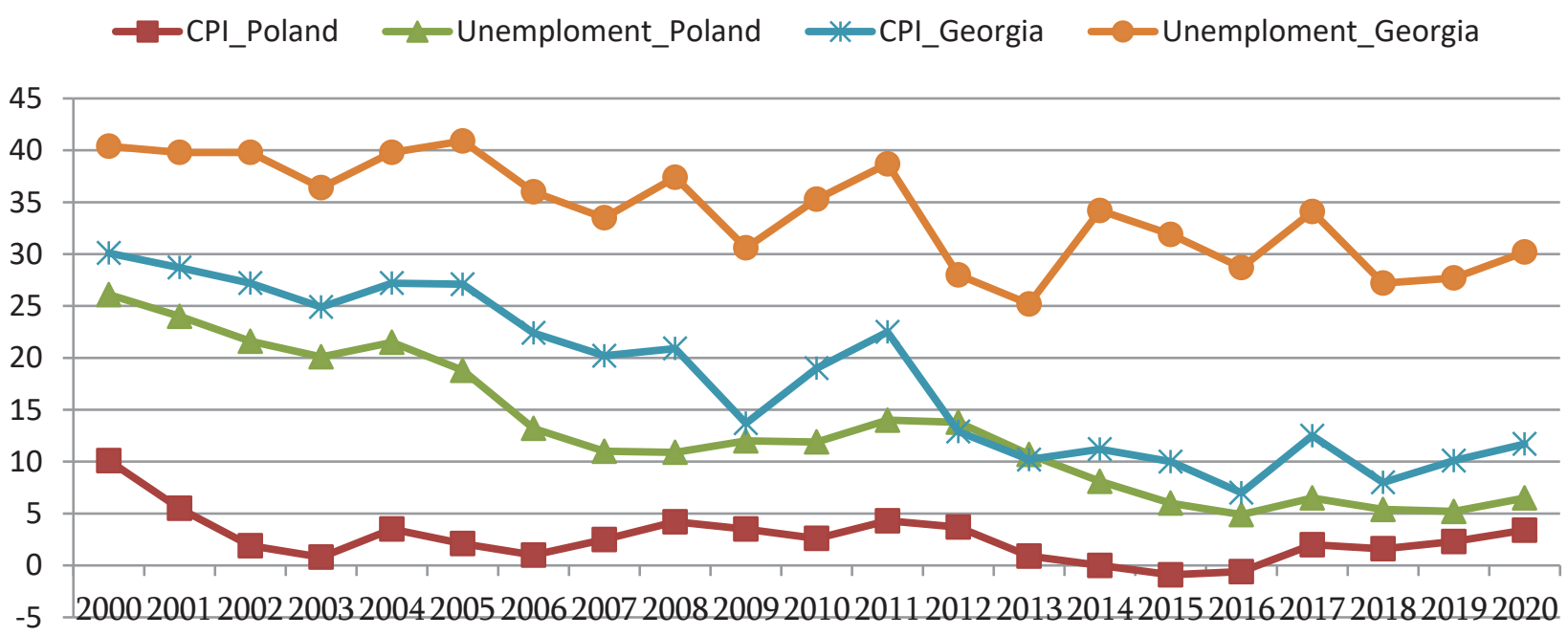

Source: Author's calculation based on Statistics Poland and The National Statistic Office of Georgia

The intensity of economic transformation and development of Poland and Georgia is reflected in various international rankings and indices. The macroeconomic stability of the country is characterized by the Economic Discomfort Index and the Rule of Law Index. EDI is a combined indicator of the gross level of severity of two macroeconomic problems in the country: unemployment and inflation, their negative impact on the economy and the level of their severity in the country. Rule of Law Index shows the level of economic order, competitive environment and protection of property as well as personal freedom and stability based on the law in the country. As the economic discomfort index is formed with the inflation and unemployment indices, it is better first to describe the trends seen in this regard in the present century in Poland and Georgia.

As already mentioned, the development of a real sector is particularly important for the sustainable and stable development of the economy as evidenced by low inflation and unemployment rates. This is why both indices are low in Poland for the two decades in question resulting in a low economic discomfort index. Both rates are higher in Georgia than in Poland, although in this case a significant difference was found when comparing unemployment rates.

Besides, because of the high rate of self-employment in Georgia (as well as in other South Caucasus countries) Philips curve is practically unusable, while in developed countries this curve indicates inverse dependence between inflation and unemployment rate. In Georgia increase in inflation, as a rule, does not impact a reduction in unemployment, and vice versa. In Georgia, Inflation has relatively modest share information of EDI, which is caused mainly by the high rate of unemployment and the prices of imported goods.

Unemployment in Poland is scattered around the natural level, so the curve is relatively smooth and reflects the economic pattern observed in the EU countries.

Statistical analysis confirmed the theoretical and preliminary assumptions, the Polish EDI curve was described with high accuracy (Determination coefficient $R 2=0.8837$ ) by the

Chart 3. Economic Discomfort Index of Poland and Georgia (2000-2020).



Source: Author's calculation based on Statistics Poland and The National Statistic Office of Georgia 
Chart 4.The unemployment rate in Poland and Georgia in 2019-2020.

\section{The Unemploment Rate}

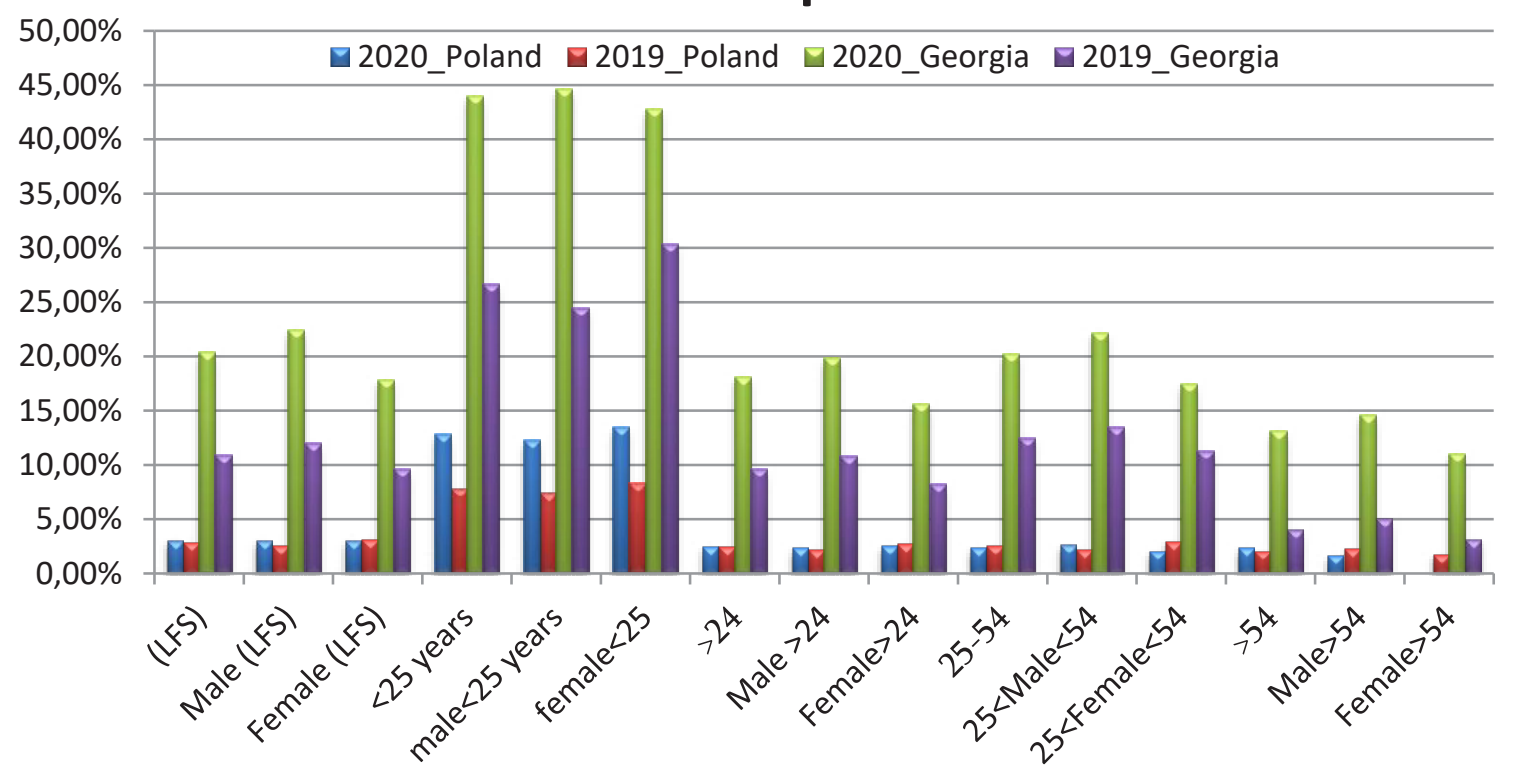

Source: The World Bank Open Date.

logarithmic function, while the same indicator is quite low for Georgia (R2=0.3525).

Unemployment constitutes the largest share of EDI in both countries (in the case of Poland it is $80.01 \%$ and for Georgia $76.26 \%$ ), but since the unemployment rate in Georgia is high, this leads to a significant deterioration in the EDI for the latter. As for the share of inflation, for Poland and Georgia, it is $19.99 \%$ and $23.74 \%$, respectively.

The average annual EDI rate for 2000-2020 is 12.9719 for Poland and 21.12381 for Georgia. The average unemployment rate and inflation rates are, respectively, 10.37143 and 2.590476 for Poland and 16.10952 and 5.014286 for Georgia.

The high economic discomfort index is a negative factor as it is a sign of macroeconomic instability and imbalance in the country. On the other hand, the lower the macroeconomic discomfort index is, the more positive the country's economic development trend is. A country's economy is more stable and resistant to risks and challenges. In the short-term perspective, the economic discomfort index will "be heavier" for all countries as a result of the pandemic. Covid-19 has affected all the countries and the world, in addition to health problems, has faced employment issues. For instance, the analysis of 2019-2020 data confirmed an unemployment growth both, in Poland and Georgia. However, in Georgia, it affected all age groups irrespective of gender, while the impact group in Poland was the youth under the age of 25. Consequently, the future perspectives of Poland are positive. See the Chart 4.

Table 1. Ranking of Poland and Georgia among the leaders and outsiders as per the Rule of Law Index).

\begin{tabular}{|c|c|c|c|c|c|c|c|c|c|}
\hline & $\begin{array}{l}\text { Constraints on } \\
\text { Government } \\
\text { Powers }\end{array}$ & $\begin{array}{l}\text { Absence } \\
\text { Corruption }\end{array}$ & $\begin{array}{l}\text { Open } \\
\text { Government }\end{array}$ & $\begin{array}{l}\text { Fundamental } \\
\text { Rights }\end{array}$ & $\begin{array}{ll}\text { Order } & \text { and } \\
\text { Security } & \end{array}$ & $\begin{array}{l}\text { Regulatory } \\
\text { Enforcement }\end{array}$ & & $\begin{array}{l}\text { Civil } \\
\text { Justice }\end{array}$ & $\begin{array}{l}\text { Criminal } \\
\text { Justice }\end{array}$ \\
\hline & Factor 1 & Factor 2 & Factor 3 & Factor 4 & Factor 5 & Factor 6 & & Factor 7 & Factor 8 \\
\hline $1^{\text {st }}$ position & Denmark-0.94 & $\begin{array}{l}\text { Denmark- } \\
0.95\end{array}$ & Norway-0.89 & Denmark-0.92 & Singapore-0.93 & Denmark-0.90 & & $\begin{array}{l}\text { Denmark- } \\
0.86\end{array}$ & Norway-0.83 \\
\hline $\begin{array}{l}\text { Poland's } \\
\text { position }\end{array}$ & $51-0.58$ & $20-0.73$ & $37-0.60$ & $39-0.64$ & $19-0.86$ & $29-0.62$ & & $34-0.63$ & $26-0.60$ \\
\hline $\begin{array}{l}\text { Georgia's } \\
\text { position }\end{array}$ & $61-0.55$ & $27-0.68$ & $41-0.57$ & $48-0.61$ & $35-0.79$ & $41-0.57$ & & $67-0.53$ & $46-0.52$ \\
\hline $128^{\text {th }}$ position & $\begin{array}{l}\text { Venezuela RB- } \\
0.17\end{array}$ & $\begin{array}{l}\text { Congo, } \\
\text { Dem.Rep.- } \\
0.16\end{array}$ & Egypt-0.22 & Iran-0.22 & $\begin{array}{l}\text { Afghanistan- } \\
.29\end{array}$ & $\begin{array}{l}\text { Venezuela } \\
0.20\end{array}$ & RB- & $\begin{array}{l}\text { Cambodia- } \\
0.26\end{array}$ & $\begin{array}{l}\text { Venezuela RB- } \\
0.13\end{array}$ \\
\hline
\end{tabular}

Source: World Justice Project. 
The legal environment is important in solving the major macroeconomic problems and achieving stable development of a country what may be evaluated through the Rule of Law Index. It is therefore interesting to analyze the worldly positions by considering the factors forming the given index and see prospects.

Progress in the given directions has an important impact on the disposition of the country society and citizens' approach to entrepreneurship and labour on the one hand and the stable economic development on the other hand.

The Rule of Low Index characterizes the situation in the country according to eight factors. Table 1 shows the ranking of the world countries, including Poland and Georgia based on the latest data of 2020.

Factor 1 (Constraints on Government Powers) measures the extent to which those who govern are bound by law. Factor 2 (Absence of corruption) measures the absence of corruption in government.

Factor 3 (Open Government ) measures whether basic laws and information on legal rights are publicized and evaluates the quality of information published by the government. Factor 4 (Fundamental Rights) recognizes that a system of positive law that fails to respect core human rights established under international law is at best "rule by law," and does not deserve to be called a rule of law system. Factor 5 (Order and Security) measures how well a society ensures the security of persons and property. Factor 6 (Regulatory Enforcement) measures the extent to which regulations are fairly and effectively implemented and enforced. Factor 7 (Civil Justice) measures whether ordinary people can resolve their grievances peacefully and effectively through the civil justice system. Factor 8 (Criminal Justice) evaluates a country's criminal justice system.

As was expected, a country solving the macroeconomic problems successfully has better legislative and executive structures. The closer the Rule of Law Index is to 1, the more chances a country has to achieve stable development and to overcome macroeconomic problems. Poland is in a much better position than Georgia in all respects. Besides, with its total index, Poland ranks the 28th and Georgia ranks the 41st among 128 countries. However, in Eastern Europe \& Central Asia regional aspect, with the same index, Georgia is the leader among 14 countries with 6 factors (I, II, III, IV, VI, VIII) and ranks the 6th in the other two cases (V, VII). As for Poland, it has not such impressive results on the regional level, as it has to compete with the world's leading countries.

According to this index, Poland and Georgia have an acceptable legal environment for economic development. In the future, it will also be interesting to discuss the economic and legal aspects of the country's stability according to the given indicators.

\section{CONCLUSION}

The rates of economic transformation and achievements of the countries have a direct effect on their regional integration, while deep integration becomes a stimulus of stable macroeconomic development of a country.

The economics of Georgia falls back most Eastern Post-Socialist countries, with less economic stability and sustainability.

Macroeconomic stability is important not only for the development of the economy but also for stability. In this regard, low unemployment and inflation rates, as well as a legal environment, are very important.

Trust in state institutions can play a positive role in terms of macroeconomic stability. In turn, the view of the measures taken by the government to some degree forms these expectations. Therefore, communication with the public is important. The public should be informed about the measures already adopted, the future arrangements, the causes and consequences of the implementation of these policies. This way, the behaviour of economic agents won't change drastically.

The full implementation of DCFTA will affect the Georgian economy in the short, medium and long term period. Thus the market will be saturated with high-quality products and resources. These circumstances will lead to better living standards. With the stabilized macroeconomic environment and modern infrastructure Georgia will become more attractive.

The economic potential of Poland is realized within the scope of the European Union as evidenced by the country succeeding in overcoming and fighting the major macroeconomic problems. Owing to low unemployment and inflation rates and a sound legislative environment, the country successfully maintains the course of stable and sustainable development.

Most of the macroeconomic problems of Georgia are associated with the failure to use the capacities of the real sector making the country import-dependent and unable to achieve such rates of unemployment and inflation to guarantee long-term macroeconomic stability within the scope of the consumer economy.

The analysis of unemployment level before and after the pandemic may be used as a lackmus of the macroeconomic stability. Poland overcame this big challenge much more successfully.

Improvement and maintenance of a sound legal base and supporting the realization of a country's economic potential in the real sector what mitigates the unemployment and inflation problems are important for sustainable macroeconomic stability. 


\section{REFERENCES:}

Berend, T.I. (2009). From the Soviet Bloc to the European Union: The Economic and Social Transformation of Central and Eastern Europe Sence 1973. Cambridge University Press.

Geostat Database (PC-AXIS Database) of National Statistic Office of Georgia. Retrieved from: http://pc-axis.geostat.ge

Karmowska, G., \& Mikiashvili, N. (2020). The assessment of development convergence among post-socialist countries based on selected indices. Journal "Economia i Środowisko - Economics and Environment" 3(74)/2020. https://doi. org/10.34659/2020/3/23

Kolodko G.W. (2019). Economics and politics of post-communist transition to market and democracy. The lessons from Polish experience. Post-Communist Economies. Volume 32, Issue 3 (2020).

Mikiashvili, N., \& Chokheli, E. (2013). The Ways for the Improvement of Competitive Environment and Some Directions of Antimonopoly Regulation (Example of Georgia). Economics and Management. 18 (3.)

Mikiashvili, N., \& Karmowska, G. (2019). The Development of Georgia and Poland Compared to Other Post-Socialist Countries. Oeconomica 2019, 352(94)1, 43-58. http://foliaoe.zut.edu.pl/Volume352(94)

Papava, V. (2003). The Basic Causes of "Dragging Out" the Transition Period. Central Asia and South Caucasus Affairs. Tokyo, The Sasakawa Peace Foundation

Papava, V. (2005). On The Theory of Post-Communist Economic Transition to Market. International Journal of Social Economics. 32(January):77-97. DOI: 10.1108/03068290510575658

Papava, V. (2013). Economic Reforms in Post-Communist Georgia: Twenty Years After. Nova Science Publishers

Papava, V. (2016). Georgia's Choice: The European Union Or The Eurasian Economic Union. Expert Opinion. Georgian Foundation for Strategic and International Studies.

Poland Macroeconomic Indicators. (2021). Statistics Poland. https://stat.gov.pl/en/poland-macroeconomic-indicators/

Sachs, J. (1993). Poland's jump to the market economy. Cambridge, MA: MIT Press.

The World Bank Open Date. (2021). https://data.worldbank.org/

Wheatley, J. (2017). Georgia from National Awakening to Rose Revolution Delayed Transition in the Former Soviet Union. Routledge

World Justice Project. Rule of Law Index (2020). Washington, DC. https://worldjusticeproject.org/sites/default/files/documents/WJP-ROLI-2020-Online_0.pdf 